'Simplicity versus Insignificance'

Author(s): A. R. C.

Source: The Musical Times, Vol. 63, No. 949 (Mar. 1, 1922), pp. 201-202

Published by: Musical Times Publications Ltd.

Stable URL: http://www.jstor.org/stable/910110

Accessed: 17-04-2016 09:56 UTC

Your use of the JSTOR archive indicates your acceptance of the Terms \& Conditions of Use, available at

http://about.jstor.org/terms

JSTOR is a not-for-profit service that helps scholars, researchers, and students discover, use, and build upon a wide range of content in a trusted digital archive. We use information technology and tools to increase productivity and facilitate new forms of scholarship. For more information about JSTOR, please contact support@jstor.org.

Musical Times Publications Ltd. is collaborating with JSTOR to digitize, preserve and extend access to The Musical Times 


\section{'JERUSALEM MY HAPPY HOME'}

Sir,-Hymns and their tunes seem to have an extraordinary fascination for English people, and at the time of writing (January 20 ) a correspondence is still proceeding in The Times Literary Supplement as to the original tune of this well-known hymn. It has brought to light some interesting facts about both hymn and tune into which I need not enter, but since The Times Literary Supplement does not use music-type, many readers have been left unsatisfied on the one point that matters to them, viz., What sort of a tune is it that is under discussion? My name was several times drawn into the correspondence, with the result that I had numerous inquiries as to the nature of the music. May I therefore satisfy further inquirers through the hospitality of your columns?

With regard to the hymn itself, Julian was unable to identify the author, and merely headed the hymn 'A Song made by F. B. P.' Mr. Joseph Gillow (Publications of the Catholic Record Society, vol. xvi., pp. 42I-2) was able to show that the initials should be 'J. B. P.' i.e., John Brerely Priest, one of the pseudonyms of the Rev. Laurence Anderton, S.J. ( $157_{6}^{5}$ to 1643$)$, whose identity with Brerely Mr. Gillow also establishes.

In I918 Miss E. M. Brougham published Corn from Olde Fieldes, a fascinating anthology of poems from the I4th to the I7th centuries, and included the hymn in its usual form of twenty-six verses (the original has fifty-nine). But the interesting thing about her book is that the frontispiece reproduces in facsimile the page from British Museum Add. MSS. 38,599 which contains the hymn. The MS. is 'the commonplace book of the Shann family of Methley, Co. York, chiefly written by Richard Shann (I59I-I627).' The page in question is headed 'The Querister's Song of Yorke in praise of Heaven'; this is followed by a line of music, to which is prefixed 'this is the tune'; then follow the words.

In 19I9 Mr. J. Britten (who opened the correspondence in The Times Literary Supplement) copied this tune, and sent it to me for identification. I had to reply that it was unknown to me, and looked more like a bass part than a melody. I have since shown it to a number of musicians, and with only one exception they incline to the belief that it is a bass and not a melody. Here is the 'tune':
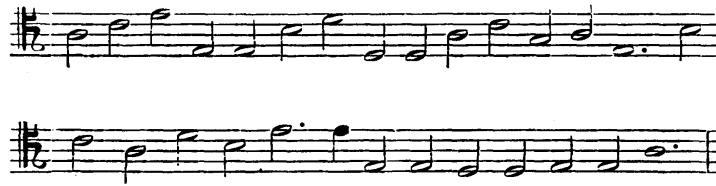

The deeper we dive into I6th century music the less dogmatic are we inclined to become. I am not prepared to assert that the 'tune' must be a bass part, but I have attempted a conjectural reconstruction of the music (in I6th century style) on that assumption, and leave the result with your readers :

\section{THE QUERISTER'S SONG OF YORKE}

Treated as a bass $C . F$.

(Treble, Alto, and Tenor parts supplied by R. R. T.)

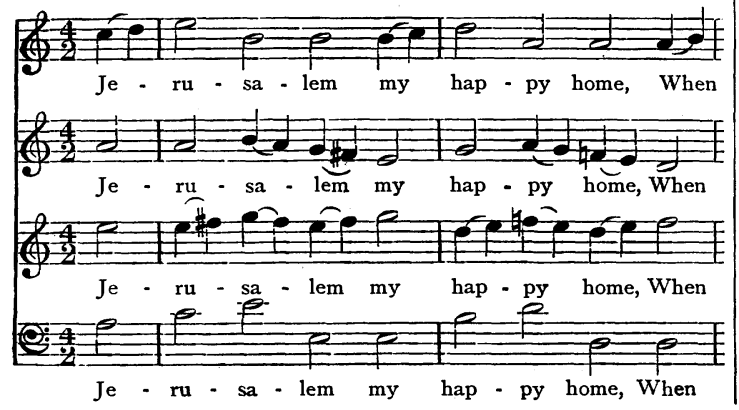

E

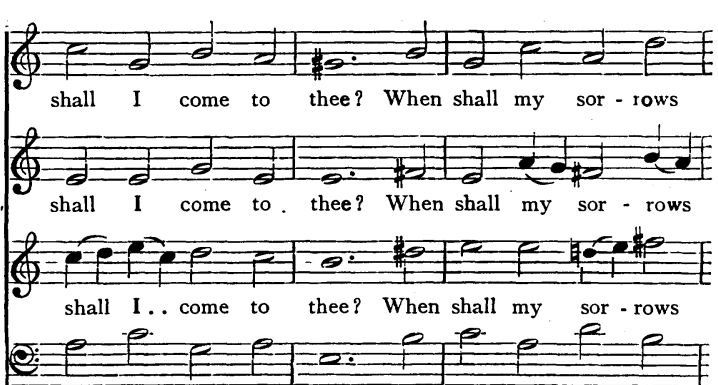

shall I come to thee? When shall my sor - rows

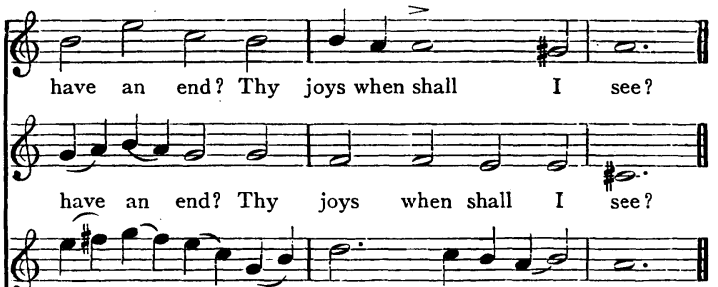

have an end? Thy joys when shall I.. see? O):

have an end? Thy joys when shall I see?

N.B.- (I) The above reconstruction contains more passing-notes than would be found in the old psalters-Ravenscroft, Day, \&c.

(2) The fifths in bars 2 and 3 are characteristic of the period: fifths and octaves were always 'saved' by the intervention of passing-note or a rest.

There is this further probability in favour of my assumption that Richard Shann has not given us the real melody: (I) I6th century psalm-tunes (like other partmusic) had their several parts written in different books; (2) The melodies of these psalm-tunes were almost invariably sung by the tenor; (3) The part-books were not always labelled with the name of the voice they represented; (4) In the present day a tenor clef implies music for a tenor voice; in the 16 th century the clef had little relation to the voice ; tenor parts constantly bore an alto clef, and bass parts were just as often as not written with a tenor clef (i.e., if their range were high). The rule was to employ (irrespective of the voice) whatever elef involved the least use of leger lines.

It is just possible that Richard Shann-knowing that psalm-tune melodies were always to be looked for in the tenor part, and seeing an unlabelled part-book bearing a tenor clef-was hastily misled into thinking that this was the part-book of the tenor voice. Such hurried or superficial examination of part-books is not unknown in later times. Some years ago I scored a Mass from a set of part-books from which the tenor one was missing. In another library was 'A Tenor Part-book' with the same Mass in its list of contents. Overjoyed at this discovery of the missing tenor, I visited the library in question, only to find that the 'missing tenor' was nothing more than the first bass part (which I already possessed) written in the tenor clef. If modern librarians can make the mistake of labelling bass part-books as 'tenor' ones, merely because they bear a tenor clef, it is not outside the bounds of possibility that Richard Shann might have fallen into the same error, and got hold of the bass part-book instead of the tenor one. But again I disclaim any intention of dogmatising. I merely put forward a theory, and am open to correction.Yours, \&c.,

R. R. TERRY.

\section{'SIMPLICITY VERSUS INSIGNIFICANCE'}

SIR, - I note that in your February issue the writer of your 'Occasional Notes' is inclined to dispute Mr. Scholes's contention that 'had the theme [of Beethoven's fifth Symphony, first movement] been changed to :

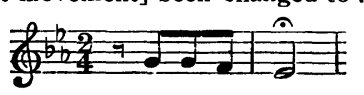


it would have been so weakened that even Beethoven could have made nothing great out of it.' The strange thing, however, is that apparently neither of these gentlemen has noticed that the theme has been changed to precisely what Mr. Scholes suggests-by Beethoven himself, in bars 14,15 .

The actual fact, it seems to me, is that the essential theme of the movement does not lie either in the exact notes as written by Beethoven in the first two bars, or in the suggested alteration of Mr. Scholes; or in any possible modification as regards pitch. It subsists in the underlying rhythmic theme, and is best represented by

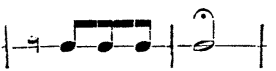

without pitch. I agree with Mr. Scholes, however, that if the opening had been altered as he suggests (so as to make it as quoted above), the movement would have been almost immeasurably weakened.-Yours, \&c.

Worthing.

A. R. C.

February 7, 1922.

\section{THE FEDERATION OF BRITISH MUSIC} INDUSTRIES

SIR, - I have, not for the first time, to express my thanks to you for your kind reference in the February number of the Musical Times to the propaganda work of this Federation.

One of the main objects of the Federation is to effect a more complete union than has hitherto existed between the art and the craft sides of music; and to this end it would be a good thing if your readers would realise what the Federation is doing for the professional musician.

The three main objects of the Federation's propaganda work are to get music recognised in the Press of the country ; to establish its claims to a recognised position in education; and to get it taken up more and more widely by employers of labour and others interested in welfare work.

The exact value of newspaper propaganda is hard to determine, but in the last twelve months we have got our articles accepted by more than fifty newspapers; and it would appear obvious that the more music is talked about, the more people will get interested in it, and a percentage at least (we hope a large percentage) of those whose interest is thus awakened will take up the study of music in one form or another.

This last result has been attained in several cases as the direct result of our Music in Industry campaign. Here we endeavour to induce employers to form choirs, bands, or orchestras among their employees. Many employers have followed our lead, and the choirs or other organizations that they have formed are being trained by local musicians. It has also been found that in very many instances employees who have joined a choir or similar body have got so interested that they have immediately begun private lessons with one or other of the local musicians available.

In our Education campaign we have actually induced sundry local Education Authorities to appoint a musical adviser ; and, quite apart from that, we have achieved less tangible but no less important results in proving through our lecturers how music may be made a fascinating and inexpensive ingredient in school curricula. There are many other ways in which the Federation can and does help professional musicians. Some of these are set forth in a booklet, Making the Most of Music, which any musician who has not yet received it can obtain on application to these offices.

I should be glad if you could spare me a little more space to put forward the other side of the case, i.e., how the professional musician can help the Federation. It is not hard to understand that it is difficult to find subjects for weekly articles which can be treated in a popular and non-technical manner, at the same time being kept free from direct propaganda of any sort or description. I personally should be very grateful for any suggestion which any of your readers would kindly send me, stipulating only that in no case can I deal with a suggestion which boosts a particular individual. For instance, I could not deal with a new system of sight-reading any more than I could advertise the merits of such a thing as the new duplex pianoforte.
Whatever the articles may be, they must not be advertisements. Secondly, the Press of the country is full of false or misleading statements about the Music Industriesstatements which are often calculated to exalt foreign at the expense of British musical instruments. If any of your readers, meeting with such statements in the columns of their local papers, would forward them instantly to the Federation, steps would immediately be taken to contradict them to the benefit of the music trades and also to the benefit of the profession, whose interests are practically identical with those of the Music Industries.

Apologising for trespassing at such length on your valuable space. - Yours, \&c.,

The Federation of British Music Industries,

II7-I23, Great Portland Street, W. I. February 7, 1922.

\section{FATHER HOWE}

Sir,- - Some of your readers may care to have a few additional particulars concerning the Howe family which have only lately come to my notice. I extract them from the article on 'The Organs at St. Stephen's Walbrook' in the January issue of The Organ, but give them in abbreviated form.

Father Howe was churchwarden of St. Stephen's in I535-36, an office held by his father (also an organ-builder) in 1519 and by his one-time partner, John Clymhoo, in 1534-35. His residence, distinguished by 'the sign of the Organe Pype,' was bought by the parish in $155 \mathrm{I}$, but he continued to rent it till his decease in $157 \mathrm{I}$. His widow, whose name was Ann, kept the house on till she, too, died. That was in 1585 . Both Howe and his wife were generously treated by the parish during their declining years, when, through no fault of their own, but through the almost entire disuse of Church organs, the old man's business was ruined and his circumstances considerably reduced. To the very end they were treated with the courtesy and consideration due to a family of repute and long-standing.

Amongst the many references to work done by Howetoo numerous to be quoted here-are several which speak of his membership of the Skinners' Company.-Yours, \&c.,

January 23, 1922. ANDREW FREEMAN.

\section{THE DEARTH OF ACCOMPANISTS}

SIR,- - They say a good accompanist is born and not made. In modern songs and chamber music the pianist often gets the lion's share of the work, but does he get a corresponding share of the credit or the fee? Oh dear, no. He gets more kicks than ha'pence, and if anything goes wrong he is the first to be blamed. Sometimes he is not even mentioned in a concert notice! He is taken for granted.

Some few years ago Miss Kathleen Peck and I sought to draw attention to this anomaly by giving a 'Song and Accompaniment' recital in London. In this case I chose the songs and played the whole programme of about twenty numbers by heart-a feat of memory that surely is not common - and yet not a single critic (and there were many present) noticed it or thought it worth recording!-Yours, \&c.

JOHN IVIMEY.

We are asked to state that the rehearsals of the Philharmonic Choir are now open to visitors on payment of $7 s, 6 d$. for the season, which sum entitles them to become honorary members. Choirmasters, singers, and others should make the most of this opportunity for hearing fine music, and of gaining valuable instruction in voiceproduction, interpretation, \&c. The rehearsals are held at the Guildhouse, Belgrave Road, Ecrleston Square, on Wednesdays, from 5.45 to $7.45 \mathrm{p} . \mathrm{m}$. The nearest station is Victoria. The hon. secretary is Miss R. Philpott, 8, Hatherley Grove, W.2.

A programme of works by Mr. J. Gerrard Williams will be given at Kolian Hall on March 27 by Miss Phyllis Carey-Foster (oprano), Mr. Osmond Davis (tenor), and Mrs. Norman O'Neill (pianoforte). 